\title{
Pelatihan Perawatan Berkala Sepeda Motor Injeksi Untuk Pemuda Putus Sekolah
}

\author{
Martias*), Ahmad Arif, Dedi Setiawan, Rifdarmon \\ Fakultas Teknik/ Pendidikan Teknik Otomotif/ Universitas Negeri Padang \\ *)Martias, $\equiv$ martiasft@gmail.com
}

(Di isioleh editor)

Revisi 29/07/2019

Diterima 11/08/2019;

Publish 03/12/2019

Kata kunci : Pelatihan, Perawatan Berkala, Sepeda Motor Injeksi, Pemuda Putus Sekolah

\begin{abstract}
Abstrak
Kenagarian alam pauh duo terletak di kecamatan pauh duo kabupaten solok selatan provinsi sumatera barat, dengan jumlah penduduk 8.126 jiwa. Masyarakat yang tidak bekejra sebanyak 354 orang atau $0,5 \%$ dari jumlah penduduk di usia kerja. Penyebab pengangguran adalah rendahnya kualitas pendidikan masyarakat dan adanya pemuda putus sekolah, mengakibatkan buruknya keadaan ekonomi masyarakat. Salah satu upaya yang dapat dilakukan untuk mengurangi jumlah pengangguran adalah dengan membuka lapangan pekerjaan baru. Minimnya bengkel sepeda motor dan banyaknya jumlah sepeda motor membuka peluang bagi pemuda putus sekolah untuk memanfaatkan keadaan ini. Oleh karena itu, Tim pengabdian bermaksud memberikan pelatihan perawatan berkala sepeda motor sistem bahan bakar injeksi elektronik. Pada pelatihan ini digunakan metode ceramah, tanya jawab, demonstrasi, pemberian tugas dan bimbingan. Setiap peserta diberikan buku penduan pelatihan. Pelaksanaan pelatihan berjalan dengan lancar dan sukses dengan ditunjukkan meningkatnya kemampuan akhir peserta dalam melakukan perawatan berkala sistem bahan bakar injeksi elektronik sesuai dengan buku panduan yang diberikan. Terakhir, dengan selesainya pelatihan perawatan berkala sistem bahan bakar injeksi elektronik ini diharapkan peserta pelatihan dapat melakukan perawatan berkala sepeda motor sistem bahan bakar injeksi elektronik secara mendiri dan dapat membangun bisnis bengkel sepeda motor secara mandiri.
\end{abstract}




\section{Analisis Situasi}

Kenagarian alam pauh duo terletak di kecamatan pauh duo kabupaten solok selatan propinsi sumatera barat adalah merupakan daerah yang subur yang diliputi oleh area persawahan dan perbukitan dan mayoritas masyarakat bekerja di daerah ini adalah sebagai petani, kendatipun demikian dengan adanya pemuda putus sekolah meninggalkan suatu permasalahan baru, dimana sebagian besar dari mereka belum mendapatkan pekerjaan yang tetap dan bahkan ada yang menganggur.

Adanya pemuda-pemuda yang putus sekolah tentunya menambah pengangguran namun disisi lain terlihat transportasi di daerah ini cukup lancar, suatu fenomena menarik terjadi dalam kehidupan masyarakat saat ini dengan ekspansi besar-besaran dari para pengusaha otomotif khususnya sepeda motor, masyarakat dapat dengan mudah memiliki sepeda motor (Muhammad, 2014).

Sepeda motor menjadi transportasi tujuan utama, disebabkan lebih praktis dan hemat bila dibandingkan dengan kendaraan roda empat terlebih lagi dengan sepeda motor mempercepat perpindahan dari suatu tempat ke tempat yang lainnya walaupun jalannya sempit (Nursetiono, 2012) dan juga sebagai alat praktis pembawa hasil barang pertanian ke pasar dan tempat pengolahan hasil pertanian dan perkebunan.

Sepeda motor yang dipakai cukup bervariasi dari berbagai merek sepeda motor, yang menariknya sepeda motor yang dipakai sudah menggunakan teknologi baru, yaitu sistem injeksi bahan bakar elektronik, sehingga keuntungannya sistem injeksi bahan bakar dapat lebih tepat dan homogen dalam percampurannya (Sugiarto, 2013). Sistem injeksi ini masih tergolong sangat baru bagi masyarakat, sehingga pengetahuan dan keterampilan masyarakat dalam perawatan dan perbaikannya masih sangat minim.

Pemahaman akan perawatan dan perbaikan sepeda motor injeksi sangat dibutuhkan bagi masyarakat agar sepeda motor injeksi tersebut dapat dipakai dalam jangka waktu yang lama. Oleh karena itu, kebutuhan service bagi sepeda motor menjadi kebutuhan rutin yang harus dilakukan oleh penggunanya (Hasan, 2018). Disamping itu juga masyarakat tidak memahami dan mengikuti penggunaan buku pedoman perawatan kendaraan bermotor (Hidayat, 2018).

Berdasarkan permaslahan diatas perlu adanya pelatihan untuk pemuda putus sekolah didaerah ini yang belum mempunyai pekerjaan tetap dan masyarakat umum, dengan judul "pelatihan perawatan berkala sepeda motor sistem bahan abakar injeksi elektronik bagi pemuda putus sekolah di kenagarian alam pauh duo kecamatan pauh duo kabupaten solok selatan". Dengan adanya pelatihan in diharapkan dapat meningkatkan pengetahuan dan keterampilan pemuda putus sekolah dan pemeliharaan dan perawatan sepeda motor sistem bahan bakar injeksi elektronik.

\section{Solusi dan Target}

Dalam pelaksanaan pengabdian kepada masyarakat pada program kemitraan masyarakat (PKM) kali ini telah dibuat solusi yaitu dengan memberikan pelatihan kepada pemuda putus sekolah menggunakan sepeda motor teknologi terbaru sistem injeksi bahan bakar elektronik. Pengetahuan dan keterampilan yang akan diberikan mulai dari pengetahuan dasar mesin, prinsip kerja mesin, komponen mesin, cara kerja sistem injeksi bahan bakar elektronik, 


\section{Suluah Bendang: Jurnal IImiah Pengabdian Kepada Masyarakat}

Vol.19, No.3, 2019

Martias, Ahmad Arif, Dedi Setiawan, Rifdarmon

perawatan dan perbaikan serta menganalisis kerusakan sepeda motor injeksi. Adapun target yang ingin dicapai mengikuti prosedur sebagai berikut :

1. Memberikan pelatihan perawatan berkala sepeda motor sistem bahan bakar injeksi elektronik yang berkaitan dengan cara penggunaan sepeda motor yang benar agar memiliki daya tahan lama serta umur panjang

2. Memotivasi pemuda putus sekolah untuk meningkatkan dan mengembangkan keterampilannya di bidang jasa perawatan berkala sepeda motor sistem bahan bakar injeksi elektronik sehingga mampu menciptkan lapangan pekerjaan dan meningkatkan kesejahteraan masyarakat.

3. Memberikan pelatihan tentang perawatan berkala sepeda motor sistem bahan baakr injeksi elektronik kepada pemuda putus sekolah dalam meningkatkan pemahaman dan keterampilan dalam perawatan dan perbaikan sepeda motor sistem bahan bakar injeksi elektronik

\section{METODE PELAKSANAAN}

\section{Tempat dan Waktu}

Pelaksanaan pengabdian kepada masyarakat diadakan di Kenagarian alam pauh duo kecamatan pauh duo kabupaten solok selatan provinsi sumatera barat. Pelatihan dipadatkan menjadi 2 hari, dari hari jumat sampai dengan sabtu, tanggal 20-21 September 2019.

\section{Khalayak Sasaran}

Sasaran utama dalam pelatihan ini adalah pemuda putus sekolah yang dikirim langsung oleh wali nagari setempat.

\section{Metode Pengabdian}

Metode yang digunakan untuk pencapaian target adalah sebagai berikut :

1. Metode ceramah

2. Metode tanya jawab

3. Metode demonstrasi dan pemberian tugas

4. Bimbingan

\section{Indikator Keberhasilan}

Adapun yang menjadi acuan indikator keberhasilan dari kegiatan pelatihan ini adalah sebagai berikut :

1. Peserta pelatihan mampu mengutamakan keselamatan kerja

2. Peserta pelatihan mampu melakukan perawatan berkala sepeda motor sistem bahan bakar injeksi elektronik sesuai dengan buku panduan yang diberikan.

3. Peserta pelatihan mampu melakukan pendiagnosaan kerusakan pada sepeda motor sistem bahan bakar injeksi elektronik dan benar

4. Peserta pelatihan mampu melakukan penyetingan dan perbaikan pada sepeda motor sistem bahan bakar injeksi elektronik sesuai buku panduan

5. Peserta pelatihan mampu membangun bisnis bengkel sepeda motor secara mandiri.

6. Peserta pelatihan mampu saling bekerja sama dalam melakukan perawatan dan perbaikan pada sepeda motor sistem bahan bakar injeksi elektronik.

\section{Metode Evaluasi}

Pelaksanaan evaluasi yang dilakukan adalah sebagai berikut : 
1. Evaluasi persiapan pelatihan : bentuk evaluasi yang dilakukan berupa pre test dan tanya jawab tentang perawatan berkala sepeda motor sistem bahan bakar injeksi elektronik.

2. Evaluasi proses pealtihan : evaluasi ini dilakukan dengan cara melihat keaktifan, keterlibatan, keantusiasan, kejujuran selama kegiatan berlangsung

3. Evaluasi akhir pelatihan : evalausi yang dilakukan terhadap hasil pelatihan dengan memberikan ujian praktikum dalam melakukan perawatan berkala sepeda motor sistem bahan bakar injeksi elektronik.

\section{HASIL DAN PEMBAHASAN}

Hasil dan pembahasan yang dilakukan adalah sebagai berikut :

1. Saat kegiatan

a. Kehadiran

Peserta yang menghadiri pelatihan sesuai dengan jumlah awal yang direncanakan adalah sebanyak 15 orang. Kehadiran peserta pelatihan dari awal sampai akhir menunjukkan rasa ingin tahu yang sangat tinggi disertai dengan ketepatan waktu dan kedisplinan. Kegiatan peatihan ini dipadatkan menjadi 2 hari semenjak tanggal 19-20 September 2019 yang dimulai dari jam 07.30-17.30 WIB.

b. Perilaku peserta

Selama pelatihan berlangsung peserta menunjukkan sikap yang baik dan saling menghargai meskipun keadaan udara pada saat itu masih terkena kabut asap, hal ini dapat kita lihat ketika pelatihan berlangsung antusiasme peserta sangat tinggi dalam bertanya dan juga disiplin mematuhi peraturan yang tealh dibuat oleh panitia pelatihan. Selama pelatihan berlangsung tidak terjadi perilaku-perilaku peserta yang menyimpang, semuanya dapat terkendali dengan baik. Seolah-olah antara instruktur dan peserta sudah berkenalan lama karena rasa kekeluargaan di kenagarian ini cukup tinggi, sehingga mempunyai keunikan tersendiri.

c. Rasa ingin tahu

Peserta selama kegiatan pelatihan diberikan alat tulis dan modul yang berisi materi perawatan berkala sepeda motor injeksi elektronik, disini terlihat peserta selama pelatihan selalu membawa modul perawatan dan perbaikan sistem bahan bakar injeksi elektronik dan sekaligus membacanya yang menunjukkan rasa keinginantahuan yang tinggi dari para peserta. Selama pelatihan sebagian besar peserta tidak segan mengajukan pertanyaan tentang perawatan berkala sistem bahan bakar injeksi elektronik. Dari rasa keinginantahuan yang besar inilah yang membuat seluruh peserta mudah dan cepat memahami materi yang telah dijelaskan oleh instruktur selama 2 hari selama pelatihan.

\section{d. Keaktifan peserta}

Setiap diberikan tugas secara mandiri untuk diperagakan di depan kelas, para peserta dengan senang hati untuk mengerjakannya dengan sungguh-sungguh dan bahkan karena begitu aktifnya para peserta berani mempraktekkan perawatan berkala sepeda motor sistem bahan bakar injeksi elektronik tanpa instruktur mendampingi. Hal ini terjadi dikarenakan peserta pelatihan sudah mulai menguasai materi praktek yang telah disampaikan oleh instruktor. Keaktifan peserta ini juga terlihat ketika istirahatpun masih ada juga peserta yang mempelajari materi teori dan mengerjakan tugas praktek yang telah diberikan. 
Suluah Bendang: Jurnal IImiah Pengabdian Kepada Masyarakat Vol.19, No.3, 2019

Martias, Ahmad Arif, Dedi Setiawan, Rifdarmon

e. Dokumnetasi awal hingga akhir pelatihan

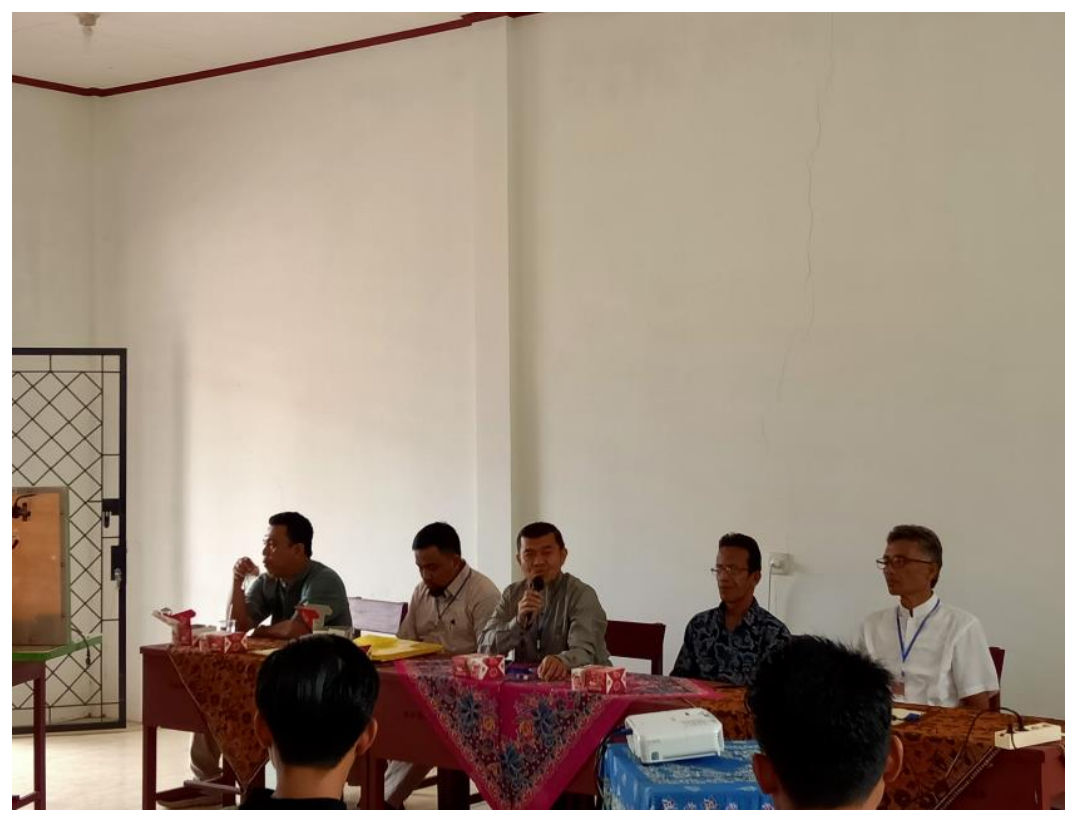

Gambar 1. Pembukaan kegiatan pelatihan

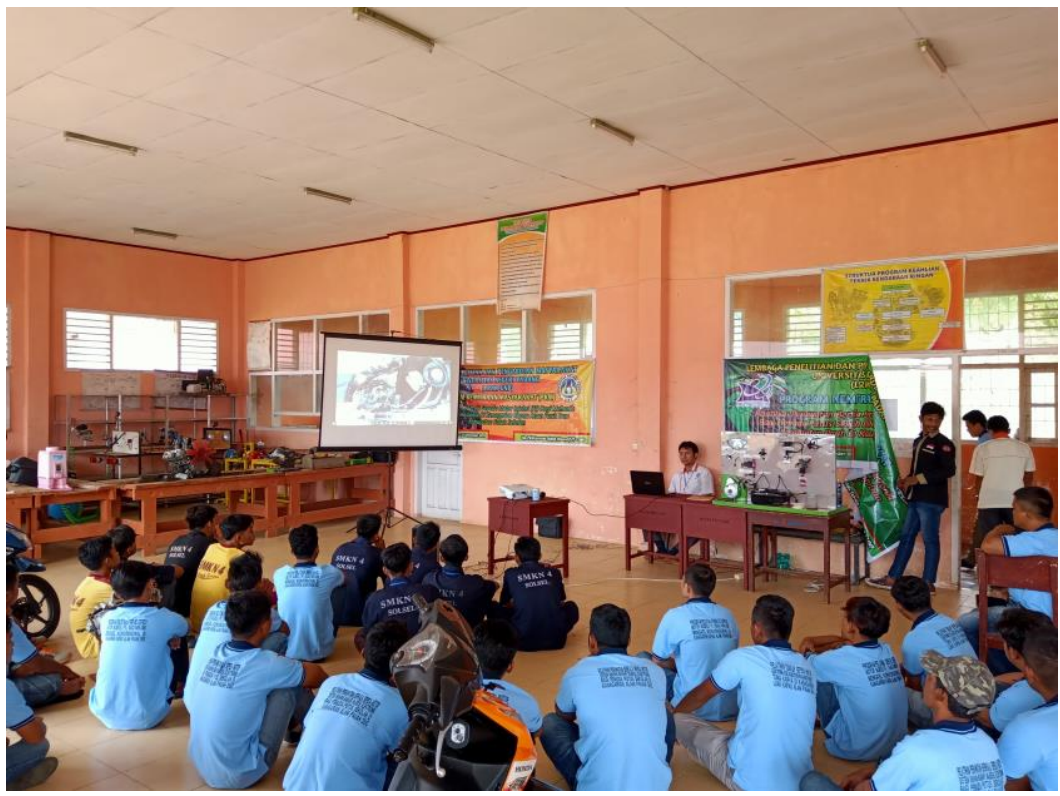

Gambar 2. Pemberian materi pelatihan 


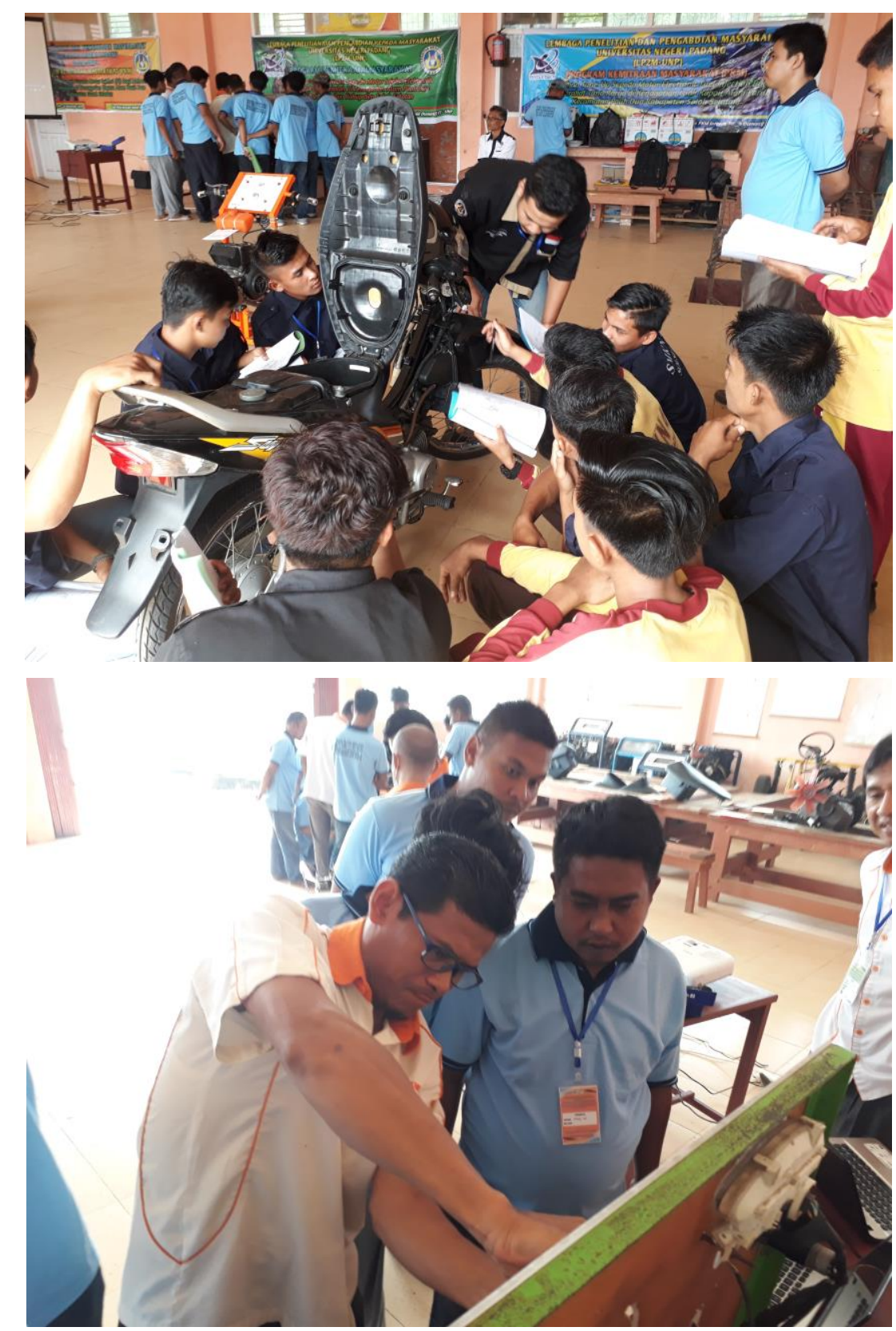

Gambar 3. Pemberian materi praktek

2. Akhir kegiatan

Pada saat evaluasi awal yang dilakukan oleh tim pengabdian, kemampuan yang dimiliki oleh peserta pelatihan menunjukkan peserta belum memahami secara keseluruhan langkah perawatan berkala sepeda motor injeksi elektronik dan pengetahuan peserta pelatihan masih terbilang sangat rendah. Evaluasi akhir ini bertujuan untuk menilai kemampuan masing-masing peserta pelatihan dalam melakukan perawatan berkala sistem bahan bakar injeksi elektronik.

Setelah dilakukan pelatihan selama 2 hari peserta mengalami perubahan kemampuan secara signifikan dalam melakukan perawatan berkala sistem bahan bakar injeksi, hal ini dibuktikan dengan evaluasi akhir yang dilakukan. Setiap peserta diuji kemampuannya dalam 
melakukan perawatan berkala sistem bahan bakar injeksi elektronik dan hasilnya sangat memuaskan, setiap peserta telah mampu melakukan perawatan berkala sistem bahan bakar injeksi elektronik secara mandiri. Kendatipun demikian, peserta pelatihan telah diberikan buku panduan perawatan berkala sistem bahan bakar injeksi elektronik supaya menjadi pedoman kembali ketika diperlukan.

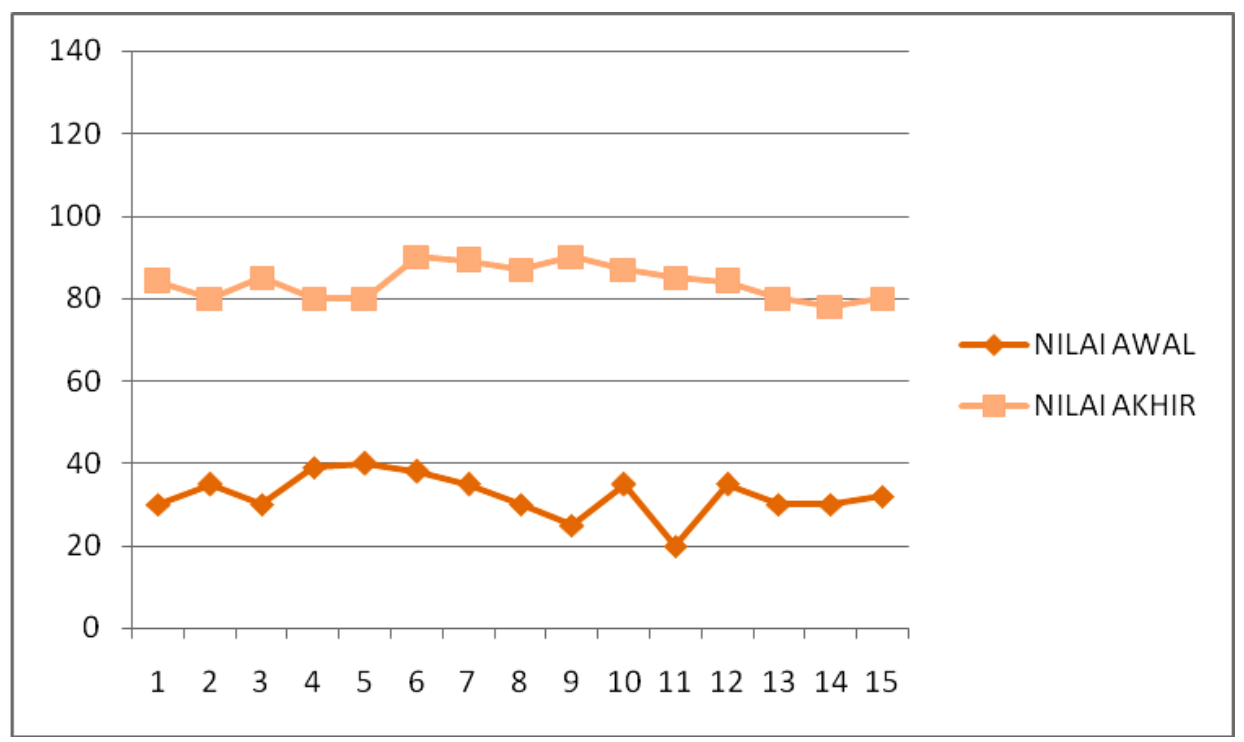

Gambar 4. Grafik peningkatan keterampilan peserta pelatihan

3. Pembahasan

Selama 2 hari mengadakan pelatihan di kenagarian alam pauh duo kecamatan pauh duo kabupaten solok selatan tim pengabdian telah mencapai sasaran dari kegiatan pelatihan yaitu memberikan dan meningkatkan kemampuan masyarakat dan pemuda purtus sekolah dalam pelatihan perawatan berkala sistem bahan bakar injeksi elektronik dengan baik dan benar. Hal itu dapat kita lihat dari hasil akhir yang menunjukkan kemampuan peserta telah berubah dari tidak bisa menjadi bisa dalam perawatan berkala sepeda motor bahan bakar injeksi elektronik. Tidak hanya itu materi teori juga sudah dikuasai sesuai dengan petunjuk yang diberikan selama pelatihan oleh instruktur.

Rasa ingin tahu yang tinggi mendorong para peserta secara keseluruhan bersemangat dalam mengikuti pelatihan. Semua peserta tidak malu untuk bertanya pada saat pelatihan diberikan sehingga semua yang ditanyakan talah didapat jawabannya, hal ini secara otomatis telah menambah keterampilan tentang perawatan berkala sepeda motor sistem bahan bakar injeksi elektronik

Kedepannya para peserta berkeinginan ada kerjasama untuk diadakan pelatihan berikutnya dengan tema yang berbeda, dengan harapan mereka akan mendapatkan pengetahuan dan keterampilan baru untuk dimasa yang akan datang, karena teknologi sepeda motor selalu berkembang sepanjang masa. Dengn diadakannya pelatihan berikutnya tentunya 
akan membuat sumber daya manusia di kenagarian alam pauh duo kecamatan pauh duo kabupaten solok selatan menjadi semakin bermanfaat.

Walaupun pelatihan telah selesai dilaksanakan namun komunikasi kedepannya diharapkan tidak terputus, karena para instruktur telah menyediakan alamat yang dapat dihubungi melalui media sosial yang ada, apabila para peserta pelatihan mengalami kesulitan pada saat melakukan perawatan berkala sepeda motor sistem bahan bakar injeksi elektronik, maka peserta dipersilakan untuk segera menghubungi alamat intstruktur yang telah ditinggalkan dan instruktur tidak akan berkeberatan menyediakan waktu dalam menjawab pertanyaan dan keluhan yang diberikan sehingga diharapkan semua pertanyaan dan keluhan dapat diatasi sesuai dengan prosedur yang ada. Walaupun demikian, Tim pengabdian menyadari bahwa selama pelatihan dilaksanakan tentunya tidak terlepas dari kekhilapan dan kesalahan serta hal itu akan diperbaiki kedepannya

\section{KESIMPULAN}

Berdasarkan pelatihan yang diberikan selama dua hari di kenagarian alam pauh duo kecamatan pauh duo kabupaten solok selatan, menunjukkan keterampilan masyarakat terutama pemuda putus sekolah telah meningkat secara signifikan dalam perawatan berkala sepeda motor sistem bahan bakar injeksi elektonik, hal ini dibuktikan dengan evaluasi akhir berada pada kategori sangat baik dan tentunya hal ini telah meningkatkan sumber daya manusia di kenagarian alam pauh duo kecamatan pauh duo kabupaten solok selatan.

Hasil yang sangat memuaskan ini telah membuka jalan bagi pemuda putus sekolah di kenagarian alam pauh duo kecamatan pauh duo kabupaten solok selatan untuk membuka lapangan pekerjaan baru secara mandiri dengan membangun bisnis bengkel sepeda motor, dan hal ini adalah menjadi tujuan utama dari diadakannya pelatihan perawatan berkala sepeda motor sistem bahan bakar injeksi oleh tim pengabdian masyarakat dari Universitas Negeri Padang.

Selain itu kegiatan pengabdian kepada masyarakat ini juga menghasilkan luaran wajib berupa satu artikel ilmiah yang dipublikasikan melalui jurnal ber ISSN. Publikasi pada media cetak dan video kegiatan berdurasi 3 s/d 4 menit. Luaran tambahan buku ber ISBN dan peningkatan penerapan IPTEK di masyarakat.

\section{DAFTAR PUSTAKA}

Muhammad, I. (2014). Pelatihan Life Skill Bidang Otomotif pada Pemuda yang Tidak Melanjutkan Studi di Kota Jambi. Jurnal Pengabdian pada Masyarakat, 29(3).

Nursetiono, A., \& INDRIANI, F. (2012). Faktor-Faktor Yang Mempengaruhi Keputusan Membeli Sepeda Motor Yamaha Matik Di Kota Semarang (Doctoral dissertation, Fakultas Ekonomika dan Bisnis).

Sugiarto, B. (2004). Sistem injeksi bahan bakar sepeda motor satu silinder empat langkah. Makara Journal of Technology, 8(3).

Hasan, I., \& Hadi, F. (2018). Pelatihan Mekanik Sepeda Motor Untuk Anak Putus Sekolah Di Kelurahan Labuhbaru Barat Kecamatan Payung Sekaki Pekanbaru. Jurnal Pengabdian UntukMu NegeRI, 2(1), 33-37. 
Suluah Bendang: Jurnal Ilmiah Pengabdian Kepada Masyarakat

Vol.19, No.3, 2019

Martias, Ahmad Arif, Dedi Setiawan, Rifdarmon

Hidayat, N., Arif, A., Setiawan, M. Y., \& Afnison, W. (2018). Peningkatan Pengetahuan dan Keterampilan Pemuda Putus Sekolah Melalui Pelatihan Perawatan Berkala Sepeda Motor. INVOTEK: Jurnal Inovasi Vokasional dan Teknologi, 18(2), 83-90. 